\title{
$T$ cells and their function in the immune response to viruses
}

\author{
K. BEŇOVÁ ${ }^{1+}$, M. HANCKOVÁ ${ }^{1+}$, K. KOČI ${ }^{2}$, M. KÚDELOVÁ ${ }^{1}$, T. BETÁKOVÁ ${ }^{1,2 *}$ \\ ${ }^{1}$ Institute of Virology, Biomedical Research Center Slovak Academy of Sciences, Dúbravská cesta 9, 84505 Bratislava, Slovak \\ Republic; '2Comenius University in Bratislava, Faculty of Natural Sciences, Department of Microbiology and Virology, \\ Bratislava, Slovak Republic
}

\begin{abstract}
Summary. - The development of $\mathrm{CD} 4^{+} \mathrm{T}$ helper cells is determined by the set of transcription factors and the genes these transcription factors transcribe. In this review, we describe the basic nature of Th1, Th2, Th9, Th17, T-follicular helper (Tfh), gamma delta $(\gamma \delta)$ T cells, and T-regulatory (Treg) cells subsets, their master regulator transcription factors and their corresponding signature cytokine production profiles. Cellular immunity plays important role during virus infection. Optimal immune response to viral infections require a gentle balance of effector responses to clear the infected cells and regulatory mechanism to prevent immunopathology. The behavior of the helper cells differs with each virus - while in some cases, the response is beneficial; in other cases, it is harmful. We discuss the protective and pathological role of $\mathrm{T}$ cell immunity against influenza A virus (IAV), respiratory syncytial virus (RSV), immunodeficiency virus type 1 (HIV-1), and hepatitis B virus (HBV) infection.
\end{abstract}

Keywords: T cell; cytokine; influenza virus; respiratory syncytial virus; hepatitis B virus; human immunodeficiency virus type 1

\section{Introduction}

The immune response elicited by virus infection is one of the main factors contributing to the pathogenesis of the disease. Both innate and acquired immune responses are essential for an effective viral clearance.

$T$ cells exert diverse functions in defense and antibody response against intracellular as well as extracellular pathogens. Naïve T cells originate from hematopoietic

"Corresponding author. E-mail: virubeta@savba.sk; phone: +4212-59302-440. "Equal contribution.

Abbreviations: $\mathrm{BATF}=\mathrm{B}$-cell activating transcription factor; Bcl-6 = B-cell lymphoma 6 transcription factor; BTLA = B- and T-lymphocyte attenuator; FOXP3 = forkhead box P3; HBV = hepatitis B virus; $\mathrm{HIV}-1$ = human immunodeficiency virus type 1; IAV = influenza A virus; IFNs = interferons; IL = interleukine; $R A$ = rheumatoid arthritis; RORC2 = retinoic acid receptor-related orphan receptor $\mathrm{C} 2$; $\mathrm{ROR} \gamma \mathrm{t}=$ retinoic acid receptor-related orphan nuclear receptor gamma $\mathrm{t}$, RSV = respiratory syncytial virus; STAT = signal transducer and activator of transcription; $\mathrm{Tfh}=\mathrm{T}$-follicular helper cells; $\mathrm{Th}=$ helper T-cells; $\mathrm{Treg}=$ T-regulatory cells stem cells in bone marrow, and then undergo the positive and negative processes of central selection in the thymus. Differentiation into specific subsets of T-cell depends on the presenting stimulus and the immunological environment. Naïve T cells are precursors for effector and memory subsets of T cells. CD $4^{+}$effector T cells, also called helper (Th) cells play pivotal roles in the humoral and cellular adaptive immune response. The helper $\mathrm{T}$ cells are divided into several distinct subsets (e.g. Th1, Th2, Th9, Th17, T-follicular helper (Tfh) and T-regulatory (Treg) cells), differentiated by their corresponding signature cytokine production profiles. These cells function in host defense against different types of infectious pathogens. They are also involved in different types of tissue damage and play important role in antibody responses. Every subset develops by producing its unique cytokines, master regulator, potential transcription factors and binding sites. $\mathrm{T}$ cell differentiation to cellular subsets is an intricate process subtly controlled by the master regulator and many regulatory signals and molecules. The balance among different subsets of $\mathrm{T}$ cell sets the stage for the acquired immunological response and play a significant role in pathogenesis. 


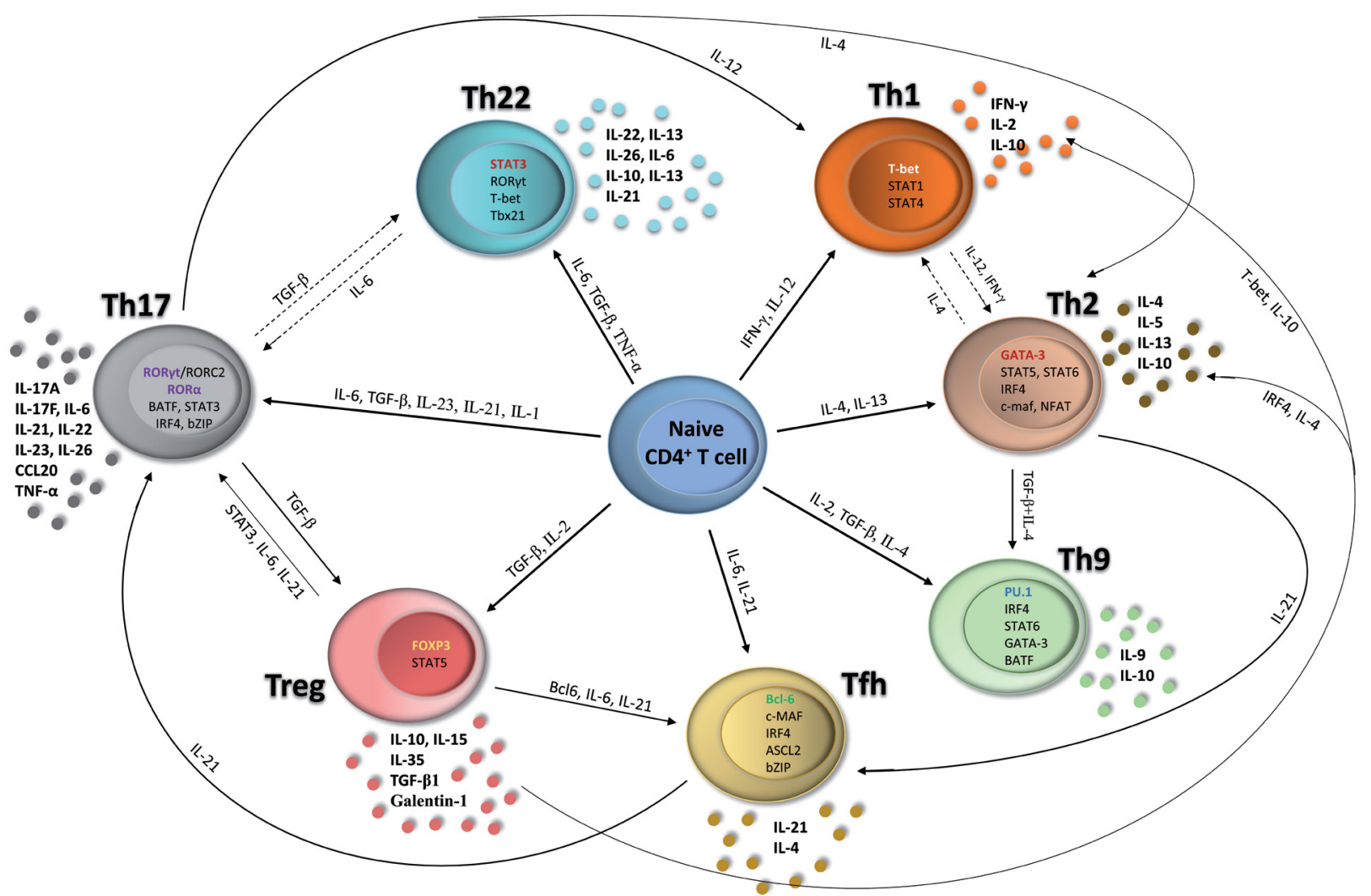

Fig. 1

Differentiation of the Th subsets

Full arrow-stimulation; dashed arrow-inhibition.

The cytokine environment activates differentiation program usually via phosphorylation of STAT proteins. This program involves the induction of transcription factors that maintain subset identity and genes involved in cell migration and cytokine production. Such signaling is essential for the ability of the Th subset to regulate immune responses (Jabeen et al., 2013). The activation of the differentiation program requires the coordinated function of a network of transcription factors.

Th1 and Th2 subsets are relatively stable, but under certain cytokine stimulation, Treg and Th17 cells switch to other $\mathrm{T}$ helper subsets. This conversion of terminally differentiated lineage committed subset to other terminally differentiated lineage committed subset is called "plasticity" (Yang et al., 2015). The defining characteristics of each subset of $\mathrm{T}$ cells are the cytokines they produce, the transcription factors they express and epigenetic changes in their specific cytokine gene loci (Fig. 1).

\section{Properties of Th1 subset}

The signature cytokines produced by the Th1 subset is interferon (IFN)- $\gamma$, IL-2, and IL-10. Th1 cells express high level of the chemokine receptors CXCR3 and CCR5 (Sallusto et al., 1998). These receptors bind chemokines, which elaborate in tissue during innate immune responses and therefore Th1 cells are abundant in sites of infection. Th1 cells also express high level of ligands for E-selectin and P-selectin, which regulate migration of immune cells to the site of severe inflammation. The master regulator of Th1 cells is considered T-bet, signal transducer and activator of transcription (STAT) 1 and STAT4. T-bet initiates the development of the Th1 lineage from naïve T-helper lymphocyte cells (Thp) by both, activating Th1 genetic programs and repressing the opposing Th2 programs. Th1 cell specific expression of IFN- $\gamma$ is associated with selective expression of T-bet (Szabo et al., 2000). T-bet represses Th2 lineage commitment through tyrosine kinase-mediated interaction between the two transcription factors (T-bet and GATA-3) that interferes with the binding of GATA-3 to its target DNA (Hwang et al., 2005). Moreover, IL- 2 and IFN- $\gamma$ secreted by Th1 cells suppress Th2 (Mosmann et al., 1986). STAT factors are required for the optimal induction of the master switch determinant. Although STAT-independent T-bet induction, has been described, it seems to be incapable to achieve a necessary 
effector function without STAT1 and STAT4 (Kaplan et al., 1998; Szabo et al., 2000). The IFN- $\gamma$ - STAT1-T-bet pathway plays an important role in Th1 differentiation in vitro (Grogan et al., 2001; Afkarian et al., 2002). IL-12 activates STAT4, which is critical for Th1 responses in vitro and in vivo (Kaplan et al., 1998; Cai et al., 2000). STAT4 is also expressed in Th2 cells, although expression level is higher in Th1 cells (Usui et al., 2003).

\section{Properties of Th2 subset}

The signature cytokines produced by the Th2 subset include interleukins - IL-4, IL-5 and IL-13. Th2 cells express the chemokine receptors CCR3, CCR4, and CCR8 (Sallusto et al., 1998). These receptors recognize chemokines that are highly produced during helminthic infection or allergic reactions, especially in mucosal tissues, where Th2 cells tend to infiltrate. STAT5, STAT6, c-Maf, GATA-3, and NFAT transcription factors are major regulators of Th2 development and function (Paul and Zhu, 2010; Lambrecht and Hammad, 2012). Induced GATA-3 activates STAT6 and facilitates chromatin remodeling of the IL4-IL5-IL13 locus during Th2 cell differentiation (Kurata et al., 1999; Lee et al., 2000; Ouyang et al., 2000; Fields et al., 2002; Avni et al., 2002; Takemoto et al., 2002; Yamashita et al., 2002). Cytokines IL-4 and IL-13 are expressed in a copy numberdependent manner at high level only in Th2 cells. IL-5 is not expressed in a copy number-dependent manner (Lee et al., 2003). Interferon regulatory factor IRF 4 is essential for the development of Th2 cells, which secrete IL-4 and IL-10 cytokines inhibiting Th1 responses (Mosmann et al., 1986; Staudt et al., 2010).

\section{Properties of Th9 subset}

Naïve CD $4^{+} \mathrm{T}$ cells and Th2 cells differentiate into Th9 cells at presence of TGF- $\beta$ (Zhou et al., 2009) The signature cytokines produced by the Th9 subset are IL- 9 and IL-10 (Dardalhon et al., 2008; Veldhoen et al., 2008). Secretion of IL-9 dependent on IL-2, is synergistically enhanced by a balanced combination of TGF- $\beta$ and IL-4, and is inhibited by IFN- $\gamma$ (Schmitt et al., 1994). B cell-activating transcription factor-like (BATF) has been shown to be required for the development of Th9, Th17 cells, T follicular helper cells, and possibly Th2 cells (Bettz et al., 2010; Schraml et al., 2009; Ise et al., 2011). TGF- $\beta$ in conjunction with IL-4 reprograms Th2 cell differentiation and results in the development of Th9 cells. The switching factor between Th2 and Th9 subsets is PU.1, which belongs to an ETS transcription factor family. The PU.1 specifically promotes the development of IL-9-secreting cells and restricts the
Th2 genetic program (Chang et al., 2005, 2009; Goswami et al., 2012a). Differentiation of Th9 is also promoted by IL-4 and several transcription factors including STAT6, GATA-3, and IRF4, which are also required for development of Th2 cells (Veldhoen et al., 2008; Staudt et al.,2010). The IFN- $\gamma$ and IFN- $\gamma$ promoting cytokines such as IL-12, IL-18, and IL-23 as well as Th1-associated transcription factor T-bet inhibit the induction of Th9 cells (Goswami et al., 2012b).

Th9 cells lack suppressive function and promote tissue inflammation. IL-9 is critically involved in the resistance to parasites (Trichuris muris) and plays a detrimental role concerning the pathogenesis of asthma (Khan et al., 2003; Temann et al., 1998; Staudt et al., 2010). Due to the pleiotropic function of IL-9, Th9 cells might be involved in pathogen immunity and immune-mediated disease.

\section{Properties of Th17 subset}

The signature cytokines produced by the Th17 subset are interleukins: IL-17A, IL-17F, IL-6, IL-21, IL-22, IL-23, IL-26, CCL20 and tumor necrosis factor alpha (TNF- $\alpha$ ) (Korn et al., 2009). Th17 cells express CCR 4 and CCR6. The CCR6 receptor binds the chemokine CCL20, which is produced by macrophages and various tissue cells after bacterial and fungal infections. In addition to CCR6, CXCR3, CXCR6 and CCR5 receptors are also expressed on the Th17 cells. Th17 cells control the immune response to extracellular pathogens such as Klebsiella or Candida, and play a key role in autoimmune diseases such as rheumatoid arthritis. Th17 cells directly or via proinflammatory cytokines modulate anti-tumor immune responses. Th17 cells are generated from naïve T cells by IL-6, IL-1, IL-21, with or without TGF- $\beta$. They further expand and stabilize with IL-23. Retinoic acid receptor-related orphan nuclear receptor gamma $\mathrm{t}(\mathrm{ROR} \gamma \mathrm{t}) /$ retinoic acid receptor-related orphan receptor C2 (RORC2) induces IL-6 expression, which is regulated by STAT3 (Laurence et al., 2007; Yang et al., 2007). The master switch factors for Th17 cells are the transcription factor ROR $\gamma \mathrm{t} / \mathrm{RORC} 2$ (mice/human), RORa, basic leucine zipper transcription factor, ATF-like (BATF), and IRF4 (Ivanov et al., 2006; Unutmaz, 2009). ROR $\gamma t$ and RORa control the key Th17 genes including IL-17A, IL-17F, IL-23R, CCL20 and CCR6 (Castro et al., 2017). The development of the Th17 phenotype is regulated by RORC2, STAT3 factors and BATF, which are part of a BATF/ Jun/IRF4 pathway (Ciofani et al., 2012; Li et al., 2012). Th17 differentiation is connected with a low concentration of TGF- $\beta$ (Zhou et al., 2008). Th17 cells can be converted after IL-12 stimulation into IFN- $\gamma$ producing Th1 cells or after stimulation with IL-4 into Th2 cells producing IL-4 (Zhou et al., 2009). 


\section{Properties of Th22 subset}

Th22 cells have been identified as a novel CD4 $4^{+} \mathrm{T}$ cells present in the skin. They primarily secrete various interleukins including IL-22, IL-6, IL-10, IL-13, IL-21, IL-26 and IL-1 $\beta$ (Eyerich et al., 2009). The signature cytokines produced by Th22 cells are IL-22, IL-26, and IL-33. CCR4, CCR6, and CCR10 expressed on the surface of Th22 cells are associated with cutaneous $\mathrm{T}$ cell homing (Duhen et al., 2009; Nograles et al., 2009).

Th22 subset is induced from $\mathrm{CD}^{+} \mathrm{T}$ cells in the presence of IL- 6 and TNF- $\alpha$. The Th22 subgroup expresses the ligand-activated master switching transcription factor, the aryl hydrocarbon receptor (AhR). By engaging this receptor and activating STAT3, Th22 cells produce a number of cytokines such as IL-22, IL-26, and IL-13 and one of the most important functional cytokine, IL-22 (Duhen et al., 2009; Ramirez et al., 2010; Akdis et al., 2012; Jabeen and Kaplan, 2012; Kaplan, 2013). The transcriptional signature of Th22 differentiation includes pronounced expression of Tbx21, cell death-inducing granzymes (particularly Gzmb), and $I L-13$. ROR $\gamma$ t and T-bet transcription factors act as positive and negative regulators of Th22 cells differentiation, respectively (Plank et al.,2017). IL-22 production in Th22 cells is stimulated by many factors, including IL-1 $\beta$, IL-6, IL-21, and IL-23 (Yeste et al., 2014; Plank et al., 2017).

Th22 cells play important role in promoting repair of damaged epithelial barriers as well as enhancing immune responses against some pathogens (Eyerich et al., 2009). Th22 cells can also express granzyme B and IL-13, factors associated with host defense and tissue remodeling (Plank et al., 2017). Elevated level of IL-22 produced by Th22 lymphocytes are associated with various disorders, such as infections, autoimmune diseases, hepatitis, pancreatitis, rheumatoid arthritis (RA), and tumors.

\section{Properties of regulatory $\mathrm{T}$ (Treg) subset}

Treg cells are divided into two groups: thymus-derived Treg cells (tTreg, or nTreg - natural Treg) and induced regulatory $\mathrm{T}$ cells (iTreg) (Sakaguchi et al., 2008). Tregs can also be classified into three new subsets: central Tregs, effector Tregs, and tissue-resident Tregs (Liston and Gray, 2014). Central Tregs (also naïve Tregs, or resting Tregs) and effector (memory) Tregs comprise the majority of all Tregs, while they are minor population of circulating and secondary lymphoid organ Tregs, respectively. Tissue-resident Tregs have a long-term residence in nonlymphoid tissues such as skin/ lung, gut, germinal center, and adipose tissue and are distinguishable from classical lymphoid-organ Treg cells in phenotype and function (Burzyn et al., 2013).
The signature cytokines produced by the Treg subset are secreted factors: IL-10, IL-15, IL-35, TGF- $\beta 1$, and Galentin-1 (Han et al., 2012). The CD3, CD4, CD25, and CD127 are surface markers that define human Treg cells(Santegoets et al., 2015). The master switch factors for Treg cells are forkhead box P3 (FOXP3) and STAT5 (Hori et al., 2003; Zhou et al., 2009). Low TGF- $\beta$ concentrations promote Th17 cell development, while high concentrations induce FOXP3 expression and Treg cell development (Zhou et al., 2008). TGF- $\beta 1$ and IL-2 are responsible for Tregs expansion. IL-2-induced STAT5 plays an important role in promoting FOXP3 expression (Zhou et al., 2009). Treg cells are predominantly activated downstream of STAT5 rather than MAPK and PI3K pathways partly due to the high expression of the phosphatase PTEN (Malek and Castro, 2010; Walsh et al., 2006). IL-2-STAT5 signaling also depends upon serine-threonine kinases Mst1 and Mst2 (Shi et al., 2018).

Tregs play a pivotal role in the preservation of self-tolerance and prevention of autoimmunity (Sakaguchi et al., 2010). In addition, Treg cells can also directly inhibit differentiation, proliferation, and function of conventional $\mathrm{T}$ cells, including $\mathrm{CD} 4^{+}$and $\mathrm{CD} 8^{+} \mathrm{T}$ cells, by direct cell-cell contact and by down-modulation of antigen presenting cells (APCs) function, especially dendritic cells (DCs) (Park et al., 2011; Maeda et al., 2014).

iTregs possess extensive plasticity and can be switched to Th1, Th2, Tfh, and Th17 cells. In the presence of B cells and CD40-CD40L interaction signaled by B-cell lymphoma/leukemia 6 (Bcl-6) transcription factor, iTregs can be switched to follicular T helper cells. IRF4 transcription factor mediates the switch of iTregs to Th2 cells and T-bet mediates the switch to Th1 cells. The conversion of iTreg to Th17 cells is regulated by STAT3 transcription factor, which is stimulated by IL-6 and IL-21 (Coomes et al., 2013).

\section{Properties of follicular helper (Tfh) cells}

Tfh cells provide a helper function to B cells and are one of the most numerous and important subsets of effector T cells in lymphoid tissues. The signature cytokine produced by the Tfh is IL-21. Tfh can also produce IL-4 (Jandl et al., 2017). Tfh cells express various receptors and proteins on their surface, including CXCR5 receptor, the inducible co-stimulatory receptor ICOS, the programmed cell death protein-1 (PD-1) and $B$ and $T$ lymphocyte attenuator (BTLA) (Akiba et al., 2005; Haynes et al., 2007; King et al., 2008). The master switch factor for Tfh cells is Bcl-6. However, the other transcription factors such as c-Maf, Achaete-scute complex homolog 2 (ASCL2), basic leucine zipper (bZIP) transcription factor, and IRF4 are also crucial. Bcl-6 expression, associated with the downregulation 


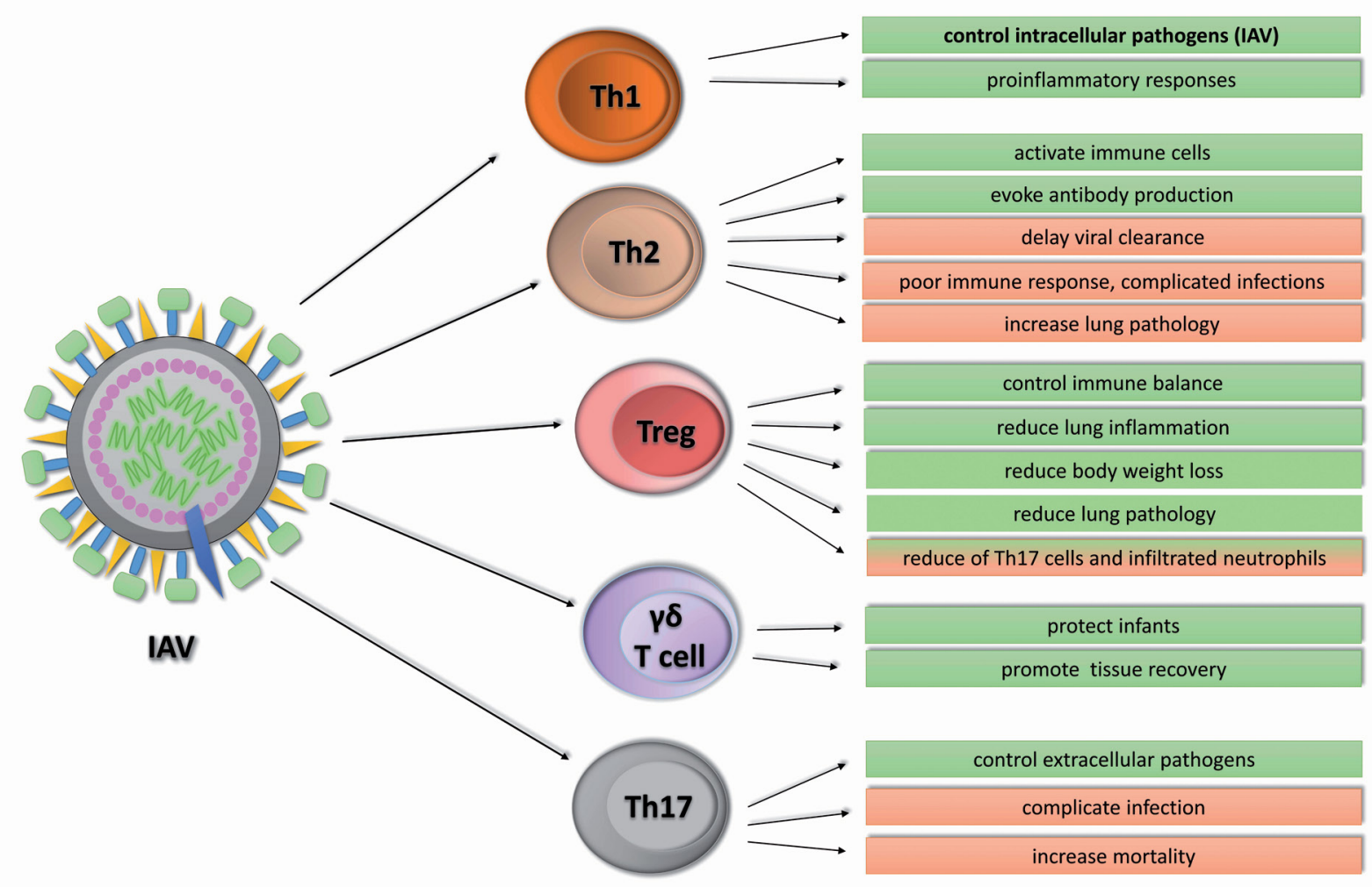

Fig. 2

A schematic representation of the Th cells subsets involved in immune response to influenza $A$ infection The positive role of individual subset is displayed in green panel and negative role is displayed in red panels.

of its antagonist Blimp-1, leads to the inhibition of the other transcription factors specific for other $\mathrm{T}$ helper cell lineages (T-bet, GATA3, and ROR $\gamma$ t especially) (Gensous et al., 2018). Tfh cells are the specialized B cell providers that help to produce antibody against foreign pathogens.

\section{Properties of gamma delta $(\gamma \delta)$ T cells}

$\gamma \delta \mathrm{T}$ cells are scarce in lymphoid tissues and abundant at mucosal sites such as skin, tongue, intestine and reproductive organs (Itohara et al., 1990). $\gamma \delta$ T cells, depending on the types of signals presented in the tissue microenvironment, produce pro-inflammatory cytokines such as IFN- $\gamma$, TNF- $\alpha$ and IL-17, as well as anti-inflammatory cytokines like TGF- $\beta$, IL-4 and IL-10, (Rochman et al. 2009; Rei et al., 2014). They also express several co-stimulatory and regulatory molecules such as CD27, CD28, CD30, B- and T-lymphocyte attenuator (BTLA), natural-killer group 2, member D (NKG2D), natural-killer group 2, member A (NKG2A), Toll-like receptors (TLRs) and CD39 (Ribot et al., 2009; Sun et al., 2013; Bekiaris et al., 2013; Nedellec et al., 2010; Wang et al., 2012; Otsuka et al., 2013). Signaling from these receptors dictates the cytokine production and $\gamma \delta$ T cells effector functions. $\gamma \delta$ T cells can also act as professional antigen-presenting cells and help in shaping the Th1 and cytotoxic CD8 ${ }^{+} \mathrm{T}$ cells response (Brandes et al., 2005).

\section{$T$ cells and respiratory viruses}

It has been thought that T-helper cells exist as two major subsets, Th1 and Th2 cells. This Th1/Th2 paradigm was based on the mechanisms involving elimination of microbial pathogens. Th1 cells are critical for the clearance of many intracellular pathogens, such as Leishmania major and viruses while Th2 cells are important for the elimination of helminthic parasites, such as Nippostrongylus brasiliensis and Schistosoma mansoni (Reiner and Locksley, 1995; Pulendran and Artis, 2012). An optimal immune response to viral infections requires delicate balance of effector responses to clear infected cells and regulatory mechanisms to prevent immunopathology (Duan and Thomas, 2016). Initial targets for respiratory viruses are lung epithelial cells and alveolar macrophages. 
The helper cells behavior differs for each respiratory virus - in some cases, the response is beneficial; in other cases, it is harmful. In many cases, Treg cells inhibit excessive virus specific $\mathrm{T}$ cell responses that may contribute to viral pathogenicity.

\section{$T$ cells and influenza $A$ virus (IAV)}

IAV is a major respiratory pathogen that causes annual epidemics with serious health consequences. IAV belongs to the family Orthomyxoviridae. The genome contains eight segments of negative-sense, single-stranded RNA. Each segment contains a viral RNA-dependent RNA polymerase and is embedded into ribonucleoproteins. The approximately $13 \mathrm{~kb}$ genome encodes up to 18 proteins. An important host innate immune mechanism is the production of interferons (IFNs), which can establish an antiviral state by up-regulating interferon stimulated genes that interfere with various steps in the virus life cycle (Švančarová et al., 2015a,b; Škorvanová et al., 2015; Lachová et al., 2017). The neutralizing antibody is considered to be the main immune mechanism against influenza virus. CD4+ T cells also play an important role in the strong Thl-based immune response to IAV infection (Fig. 2). Tfh cells are required for highly specific and memory humoral responses (Miyauchi, 2017). Oh and Eichelberger (2000) have showed that DC infected with influenza virus A/PR/8/34 (PR8) stimulate T cells which produce different types of cytokines in a dose-dependent manner. The mixed Th1/Th2 response was influenced by NA activity. It has recently been shown, that increased pathogenicity of NS1-truncated virus (NS80) does not influence Th1/Th2 balance (Turianová et al., 2020). Th2 cytokines such as IL-4, IL-5, IL-6, IL-10 and IL-13, are associated with the development of the influenza virus encephalopathy and increased pathology (Betáková et al., 2017). Lethal influenza virus infection induces cytokine profiles corresponding to the mixed Th1/Th2 response in mice (Turianová et al., 2019). Th2-controlled immune responses to influenza virus infection exacerbate lung tissue damage and delay viral clearance (Graham et al., 1994; Turianová et al., 2019). A dysregulated Th1/Th2 cytokine profile was detected in pregnant ferrets, resulted in a poor immune response against IAV infection (Yoon et al., 2018). During severe infection with pandemic influenza A(H1N1), the imbalance between pro-inflammatory and anti-inflammatory molecules, such as Th1 and Th17 cytokines, is associated with complicated infections and mortality (Sarda et al., 2019).

Infants suffer from relatively high hospitalization rates, severe clinical complications, and influenza related mortality. Exaggerated type 2 responses that are char- acteristic of the IL-33 mediated infant immune system pathway may function to prevent tissue damage due to excessive inflammation (de Kleer et al., 2016; Saluzzo et al., 2017). $\gamma \delta$ T cells are the first T cells to appear in the thymus during fetal development and have the ability to recognize a wide range of antigens and respond rapidly to infections. For example, it is known that these cells play an important role in protecting infants from viral infection (Chien et al., 2014; Vantourout and Hayday, 2013). These cells have some important roles in regulating the production of IL-17A and IL-33, in promoting tissue recovery after infection (Guo et al., 2018).

Tregs can control immune balance during viral infection and prevent tissue damage (Moser et al., 2014). The presence of Treg cells in lungs of IAV infected mice resulted in decrease of Th17 cells, infiltrated neutrophils, and lung inflammation (Egarnes and Gosselin, 2018). mTregs persist in host long time after primary IAV infection. They have a competitive advantage in migrating to the IAV-infected lungs. Adoptively transformed mTregs are able to significantly reduce body weight loss, lung pathology and infiltration of immune cells into infected lungs (Lu et al., 2019).

\section{T cells and respiratory syncytial virus (RSV)}

RSV is common respiratory virus that causes viral bronchiolitis and pneumonia in the children worldwide. In addition, it causes considerable morbidity and mortality in infants, in the immunocompromised, and the elderly. Seventy percent of children are infected with RSV in their first year of life (Bueno et al., 2008). RSV as a member of the Paramyxoviridae family, is an enveloped RNA virus and its RNA encodes 11 proteins. Both innate and acquired immune responses are essential for effective viral clearance. Since an antibody hampers infection and an effective B-cell response with efficient neutralizing antibodies is absent, the clearance of RSV infection is predominantly dependent on $\mathrm{T}$ cells response (Fig. 3) (Gonzáles et al., 2012). Th1 and Treg cells play an important role in virus clearing. Moreover, $\gamma \delta$ T cells are critical in protecting infants from RSV infection (Vantourout et al., 2014).

During the RSV infection, Tregs are maintained in the immunological environment with a focus on virus clearance. During the second infection, the Tregs' response is decreased. Secondary RSV infection leads to an increased Th17 response, where a defective Tregs' response leads to Th2-mediated airway inflammation. Initially, the severity of RSV infection is associated with the induction of Th2 cells rather than Th1 cells (Becker, 2006; Durant et al., 2013). However, the Th17 and Treg subsets have been 


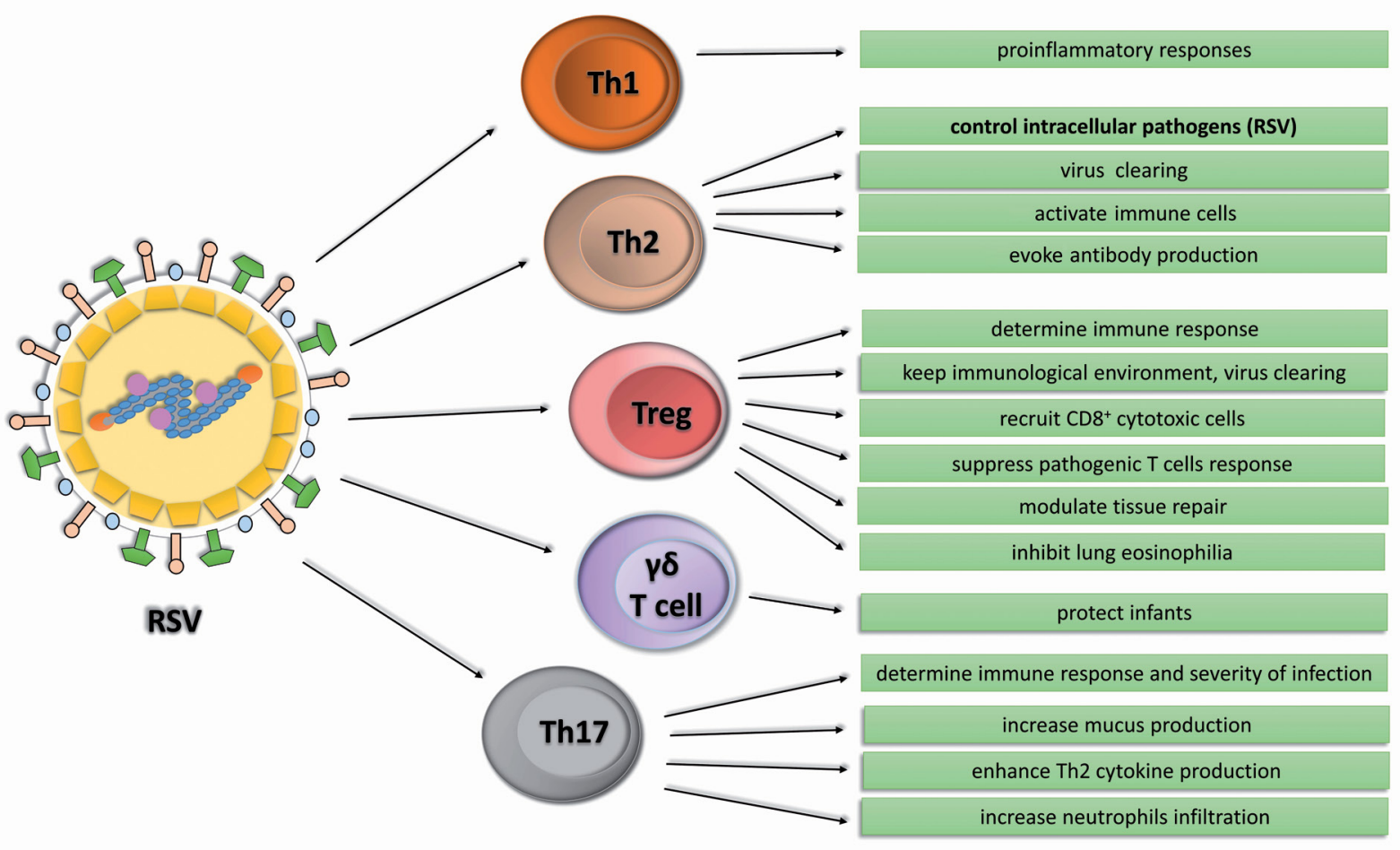

Fig. 3

A schematic representation of the Th cells subsets involved in immune response to respiratory syncytial virus The positive role of individual subset is displayed in green panel.

shown to determine the nature of the immunological response and the severity of RSV infection. During RSV infection, Treg cells are responsible for early recruitment of activated $\mathrm{CD}^{+}$cytotoxic cells into the lungs in order to regulate/facilitate RSV viral clearance (Ruckwardt et al., 2009; Fulton et al., 2010). In Treg-depleted mice, the abundant presence of CD8 + T cells producing TNF- $\alpha$ and IFN- $\gamma$ lead to tissue pathology and increased disease severity (Fulton et al., 2010; Durant et al., 2013). Treg cells perform vital anti-inflammatory functions, suppressing pathogenic $\mathrm{T}$ cell responses and inhibiting lung eosinophilia (Durant et al., 2013).

Treg response is different during primary and secondary RSV infection. During primary Th17 response, the concomitant reaction is Th2 response (Mukherjee et al., 2011; Bystrom et al., 2013). The Th17 response is induced by activated complement factor $\mathrm{C} 3$ and tachykinins (Bera et al., 2011). IL-17 causes exaggerated mucus production, increases Th2 cytokine production, it is associated with increased neutrophils infiltration in the lungs, and diminishes viral clearance by negative regulation of T-bet and Eomes transcription factors (Mukherjee et al., 2011; Bystrom et al., 2013).

\section{T cells and human immunodeficiency virus type 1 (HIV-1)}

HIV-1 belongs to the Retroviridae family, the subfamily Orthoretrovirinae and it is grouped into the genus Lentivirus. The development of infection has several phases. First, the eclipse phase is a period between 1- and 2-weeks post infection, during which the virus replicates and spreads from the site of infection into various tissues and organs (Coffin and Swanstrom, 2013). The second phase is referred as an acute phase of infection characteristic of a rapid increase in viremia and a concomitant decrease in the $C D 4^{+} \mathrm{T}$ cells population (particularly in gut lymphoid tissue, GALT). During the third phase, clinical latency develops after activation of host-specific cellular immunity, the level of viremia is usually low and this stage may last up to 20 years. During this phase, some virus replication may occur and cause a decrease in the number of $\mathrm{CD}^{+}{ }^{+} \mathrm{T}$-cell via immune activation. Phase fourth is characterized by a loss of control of the immune system, leading to opportunistic infections, malignancies, and death of untreated individuals. HIV-1 infection causes hyperactivation of the immune system and constant depletion of helper CD4 $4^{+} \mathrm{T}$ cells (Catalfamo et al., 2012). 


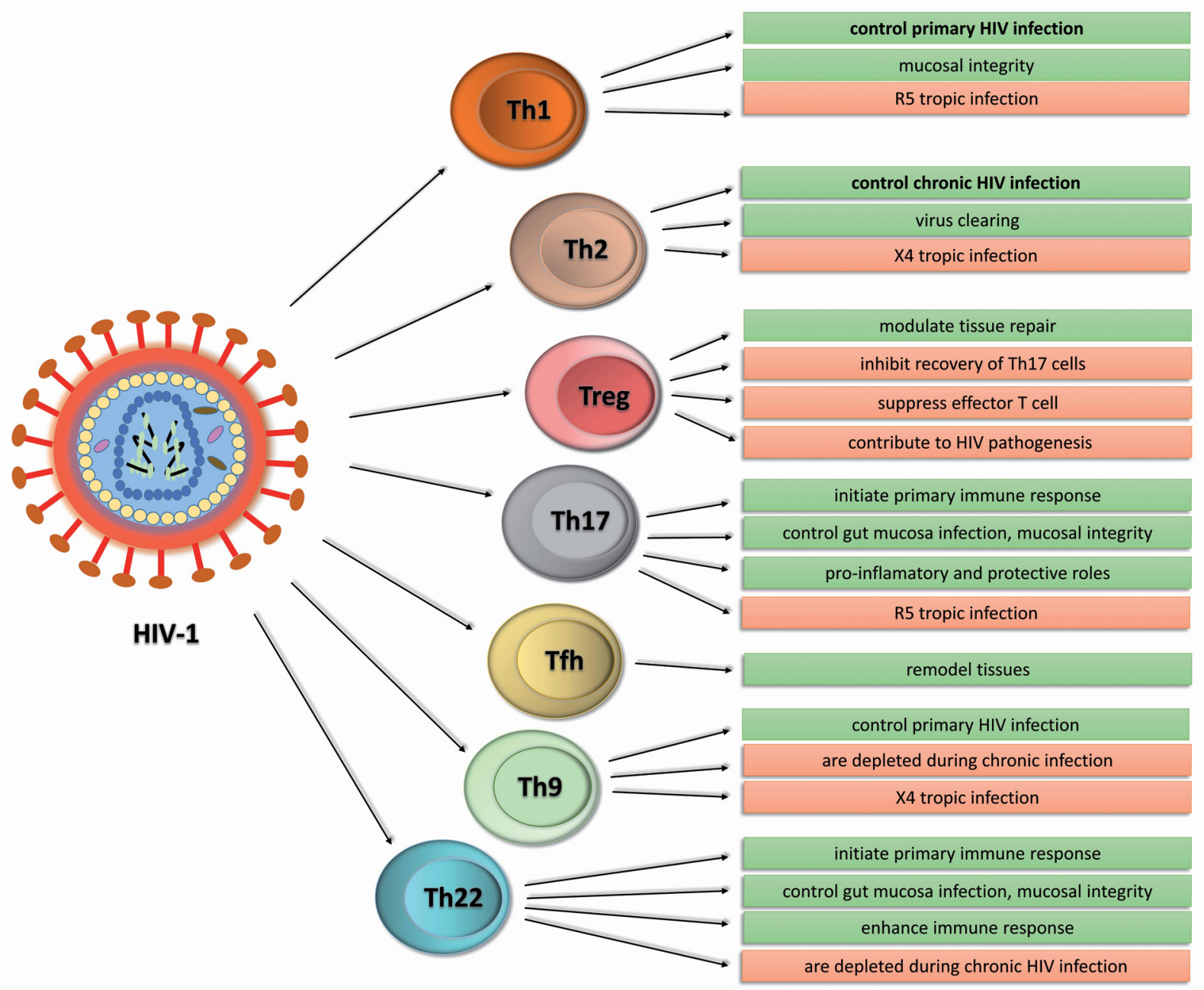

Fig. 4

A schematic representation of the Th cells subsets involved in immune response to human immunodeficiency virus type 1 The positive role of individual subset is displayed in green panel and negative role is displayed in red panels.

During pathogenesis of HIV, effector functions of $\mathrm{CD}^{+}$ $\mathrm{T}$ cells depend on cytokine immunity and CD4 ${ }^{+} \mathrm{T}$ cells differentiate into Th1, Th2, Th9, Th17, Th22 as well as Treg and Tfh cell populations (Fig. 4) (Reuter et al., 2012; Gorenec et al., 2016). Th1, Th17, and Th22 cells are critically important for initiating primary immune responses and for maintenance of mucosal integrity. Infection and dysregulation of Tfh and other key CD4+ T cell results in hyperactive, yet non-protective immune responses that supports active viral replication and evolution, and thus persistence in host tissue reservoirs (Veazey, 2019). Chronic HIV infection is characterized by Th1 and Th2 production (Gorenec et al., 2016). The number of Th17 cells is depleted in the gut mucosa, where they play a key role in a host defense against bacteria (Shirazi and Pitha, 1992). Th17 cell regeneration is inhibited by Tregs (Favre et al., 2010). However, HIV recovery was shown to be lower when $\gamma \delta$ T cells were present (James et al., 2020). Tregs play both a positive but also negative role in the pathogenesis during HIV infection. Strong Treg responses may contribute to the pathogenesis of HIV by suppressing HIV-specific immune responses, particularly effector T cells (Kinter et al., 2007). Tfh cells are located in a tissue that undergoes significant remodeling during HIV infection (Estes et al., 2007). Chronic HIV infection leads also to depletion of Th9 and Th22 cell subsets (Kim et al., 2012; Gorenec et al., 2016). Reduced IL-22 production and Th22 depletion in the gut mucosa are important factors in HIV mucosal immunopathogenesis (Kim et al., 2012). The development of $\mathrm{T}$ cell response depends on the HIV virus tropism. Th9 cells and, to a lesser extent, Th2 cells express higher surface levels of CXCR4, and are more 


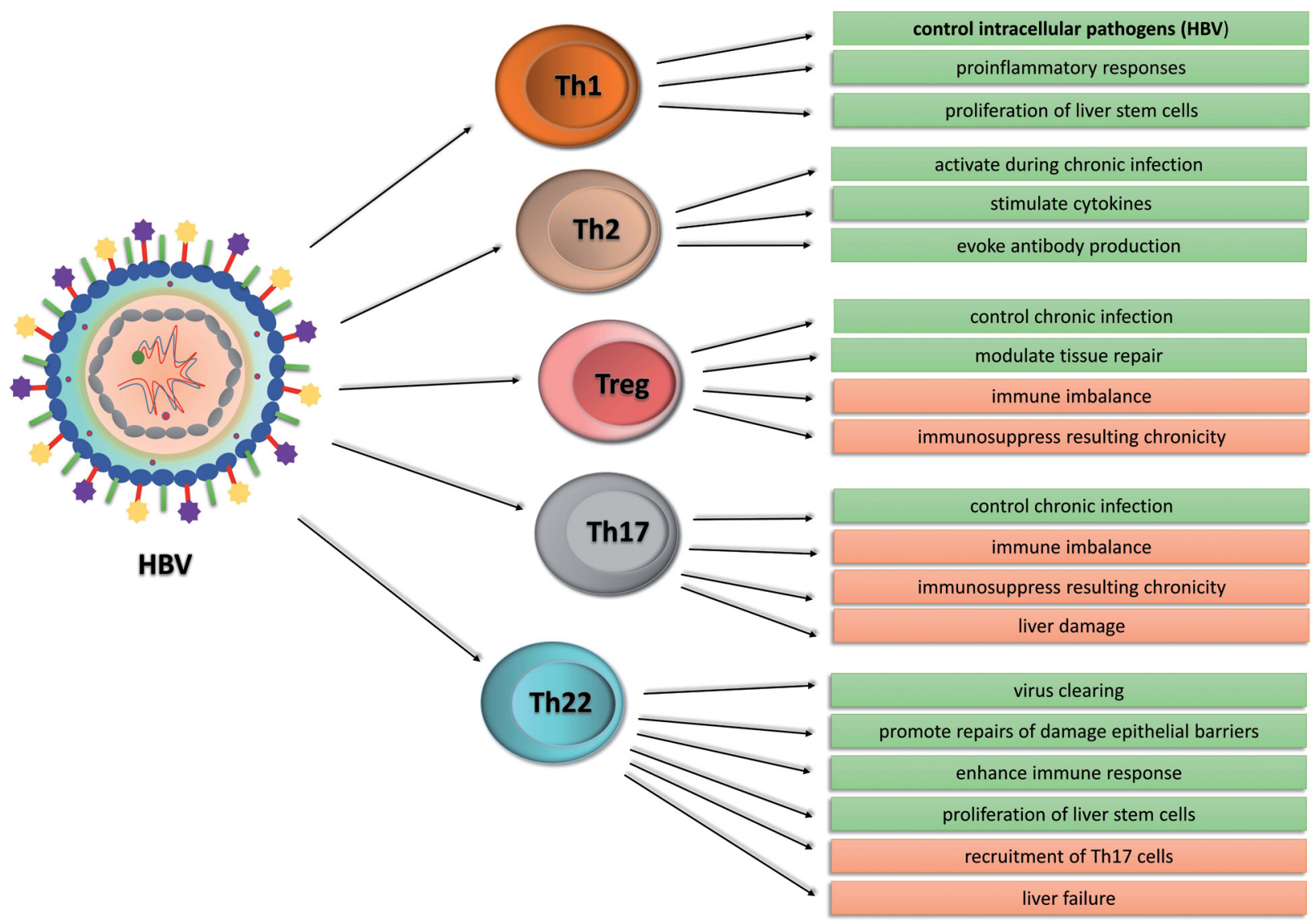

Fig. 5

A schematic representation of the Th cells subsets involved in immune response to hepatitis $B$ infection The positive role of individual subset is displayed in green panel and negative role is displayed in red panels.

permissive to $\mathrm{X} 4$-tropic infection in vitro. Th1 and Th17 cells exhibit stronger surface expression of CCR5, and are more susceptible to infection by R5-tropic viruses (Orlova-Fink et al., 2017).

\section{T cells and hepatitis B virus (HBV)}

HBV, a member of the Hepadnaviridae family, is a small DNA virus, which replicates through an RNA intermediate and can integrate into a host genome. HBV infects more than 300 million people worldwide and it is a common cause of a wide range of liver diseases ranging from acute (including fulminant hepatic failure) to chronic hepatitis, cirrhosis, and hepatocellular carcinoma. Although, most adults infected with the virus recover, $5 \%-10 \%$ are unable to clear the virus and become chronically infected. Chronically infected persons usually suffer mild liver disease with little or no long-term morbidity or mortality. However, some individuals with a chronic HBV infection develop an active disease that can progress to cirrhosis and liver cancer.

HBV-associated liver damage is thought to be mediated by immunity (Fig. 5). It is believed that immune imbalance of Treg and Th17 exists in the chronic hepatitis B. Treg cells increase at the beginning of infection and then decrease with the virus clearance. However, changes of the Th17/ Treg cells ratio could lead to immune suppression, resulting in the virus leakage to the immune system and chronic disease (Gao et al., 2015). Th17 cells produce IL-17, a major effector cytokine that could recruit and activate immune cells into the liver and lead to tissue injury (Zhang et al., 2010; Ge et al., 2010). Moreover, IL-17 could exacerbate liver fibrosis by facilitating the activation of hepatic stellate cells to myofibroblasts via signal transducer and activator of STAT3 (Meng et al., 2012). Transcriptional factor BATF regulates the Th17 differentiation and its over-expression might increase Th17 cell response, whereby the factor is related to disease progression in chronic HBV infection (Wang et al., 2018). In contrast, Chen et al. (2019) have 
shown that BATF interference significantly impedes proliferation of Th17 cells and secretion of IL-17 and IL-22, resulting in alleviated hepatic lesions.

Patients with acute hepatitis B displayed significantly elevated plasma level of IL-35 and the frequency of Th17 induced by circulating HBV peptides. IL-35 expression negatively correlated with the liver inflammation, contributing to immunosuppression in chronic hepatitis modulated by Th17 and Treg cells. IL-35 may be a novel mediator associated with hepatocyte damage and liver inflammation by regulating HBV peptides-induced Th17 cells during acute HBV infection (Teng et al., 2019).

Cytokine IL-22 can stimulate innate immune responses against pathogens and target particularly hepatocytes, keratinocytes, lung, and intestine cells (Thompson et al., 2010). IL-22 plays two leading roles in the body, proinflammatory and protective. In humans, IL-22 appears to be produced primarily by Th1 and Th22 $\mathrm{T}$ cell subsets and IL-22-producing cytotoxic T cells, as well as Th17 cells (Sonneberg et al., 2011). The direct antiviral effect of IL-22 is utterly insignificant, and cannot promote classical IFN-stimulated antiviral pathways and mediators (Wang et al., 2013). In the liver of mice and patients with chronic HBV infection, inflammatory cells produce IL22 , which promote proliferation of liver stem/progenitor cells by STAT3 (Feng et al., 2012). However, IL-22 plays a pathological role in exacerbating chronic liver inflammation and fibrosis by recruiting Th17 hepatic cells in HBV infected patients (Zhao et al., 2014). Persistently elevated circulating Th22 reversely correlates with the prognosis of acute-on-chronic liver failure, associated with hepatitis B virus (Mo et al., 2017).

Acknowledgment. This work was supported by the Slovak Research and Development Agency (grand No. VEGA2/0031/20).

\section{References}

Afkarian M, Sedy JR, Yang J, Jacobson NG, Cereb N, Yang SY, Murphy TL, Murphy KM., Nat. Immunol. 3, 549-557, 2002. https://doi.org/10.1038/ni794

Akdis M, Palomares O, van de Veen W, van Splunter M, Akdis CA., J. Allergy Clin. Immunol. 129, 1438-1449, 2012. https:// doi.org/10.1016/j.jaci.2012.05.003

Akiba H, Takeda K, Kojima Y, Usui Y, Harada N, Yamazaki T, Ma J, Tezuka K, Yagita H, Okumura K., J. Immunol. 175, 2340-2348, 2005. https://doi.org/10.4049/iimmunol.175.4.2340

Avni O, Lee D, Macian F, Szabo SJ, Glimcher LH, Rao A., Nat. Immunol.3, 643-651,2002. https://doi.org/10.1038/ni808

Becker Y,Virus Genes 33, 235-252, 2006. https://doi.org/10.1007/ s11262-006-0064-X
Bekiaris V, Sedy JR, Macauley MG, Rhode-Kurnow A, Ware CF., Immunity 39,1082-1094,2013.https://doi.org/10.1016/j. immuni.2013.10.017

Bera MM, Lu B, Martin TR, Cui S, Rhein LM, Gerard C, Gerard NP., J. Immunol. 187, 4245-4255, 2011. https://doi. org/10.4049/jimmunol.1101789

Betakova T, Kostrabova A, Lachova V, Turianova L., Curr Pharm Des. 23, 2616-2622, 2017. https://doi.org/10.2174/138161 2823666170316123736

Bettz BC, Jordan-Williams KL, Wang C, Kang SG, Liao J, Logan MR, Kim CH, Taparowsky EJ., J. Exp. Med.207, 933-942, 2010. https://doi.org/10.1084/jem.20091548

Brandes M, Willimann K, Moser B., Science 309, 264-268, 2005. https://doi.org/10.1126/science.1110267

Bueno SM, González PA, Pacheco R, Leiva ED, Cautivo KM, Tobar HE, Mora JE, Prado CE, Zúñiga JP, Jiménez J, Riedel CA, Kalergis AM., Int. Immunopharmacol. 8, 1320-1329, 2008. https://doi.org/10.1016/j.intimp.2008.03.012

Burzyn D, Kuswanto W, Kolodin D, Shadrach JL, Cerletti M, Jang Y, Sefik E, Tan TG, Wagers AJ, Benoist C, Mathis D., Cell 155, 1282-1295, 2013. https://doi.org/10.1016/j. cell.2013.10.054

Bystrom J, Al-Adhoubi N, Al-Bogami M, Jawad AS, Mageed RA., Viruses 5, 777-791, 2013. https://doi.org/10.3390/ v5030777

Cai G, Radzanowski T, Villegas EN, Kastelein R, Hunter CA., J. Immunol. 165, 2619-2627, 2000. https://doi.org/10.4049/ jimmunol.165.5.2619

Castro G, Liu X, Ngo K, De Leon-Tabaldo A, Zhao S, Luna-Roman R, Yu J, Cao T, Kuhn R, Wilkinson P, Herman K, Nelen MI, Blevitt J, Xue X, Fourie A, Fung-Leung WP., PloS One 12, e0181868, 2017. https://doi.org/10.1371/journal. pone. 0181868

Catalfamo M, Le Saout C, Lane HC., Cytokine Growth Factor Rev. 23, 207-214, 2012. https://doi.org/10.1016/i.cytogfr.2012.05.007

Ciofani M, Madar A, Galan C, Sellars M, Mace K, Pauli F, Agarwal A, Huang W, Parkhurst CN, Muratet M, Newberry KM, Meadows S, Greenfield A, Yang Y, Jain P, Kirigin FK, Birchmeier C, Wagner EF, Murphy KM, Myers RM, Bonneau R, Littman DR., Cell 151,289-303,2012.https:// doi.org/10.1016/j.cell.2012.09.016

Coffin J, Swanstrom R., Cold Spring Harb. Perspect. Med. 3, a012526, 2013. https://doi.org/10.1101/cshperspect. $\underline{\mathrm{a} 012526}$

Coomes SM, Pelly VS, Wilson MS., Open Biol.3, 1-15,2013. https:// doi.org/10.1098/rsob.120157

Chang HC, Han L, Jabeen R, Carotta S, Nutt SL, Kaplan MH., J. Immunol. 183, 4887-4894, 2009. https://doi.org/10.4049/ ¡immunol.0900363

Chang HC, Zhang S, Thieu VT, Slee RB, Bruns HA, Laribee RN, Klemsz MJ, Kaplan MH., Immunity 22, 693-703, 2005. https://doi.org/10.1016/j.immuni.2005.03.016

Chen LY, Fan XP, Fan YC, Zhao J, Gao S, Li F, Qi ZX, Wang K., Dig. Dis. Sci. 64, 773-780, 2019. https://doi.org/10.1007/ s10620-018-5392-x 
Chien YH, Meyer C, Bonneville M., Annu. Rev. Immunol. 32, 121-155, 2014. https://doi.org/10.1146/annurev-immunol-032713-120216

Dardalhon V, Awasthi A, Kwon H, Galileos G, Gao W, Sobel RA, Mitsdoerffer M, Strom TB, Elyaman W, Ho IC, Khoury S, Oukka M, Kuchroo VK., Nat. Immunol. 9, 1347-1355, 2008. https://doi.org/10.1038/ni.1677

de Kleer IM, Kool M, de Bruijn MJ, Willart M, van Moorleghem J, Schuijs MJ, Plantinga M, Beyaert R, Hams E, Fallon PG, Hammad H, Hendriks RW, Lambrecht BN., Immunity 45, 1285-1298, 2016. https://doi.org/10.1016/j. immuni.2016.10.031

Duan S, Thomas PG., Front. Immunol. 7, 1-16, 2016. https://doi. org/10.3389/fimmu.2016.00025

Duhen T, Geiger R, Jarrossay D, Lanzavecchia A, Sallusto F., Nat. Immunol. 10, 857-863, 2009. https://doi.org/10.1038/ ni. 1767

Durant LR, Makris S, Voorburg CM, Loebbermann J, Johansson C, Openshaw PJ., J.Virol. 87,10946-10954, 2013. https:// doi.org/10.1128/JVI.01295-13

Egarnes B, Gosselin J., Front. Immunol. 9, 1-12, 2018. https://doi. org/10.3389/fimmu.2018.00132

Estes JD, Wietgrefe S, Schacker T, Southern P, Beilman G, Reilly C, Milush JM, Lifson JD, Sodora DL, Carlis JV, Haase AT., J. Infect. Dis. 195, 551-561, 2007. https://doi. org/10.1086/510852

Eyerich S, Eyerich K, Pennino D, Carbone T, Nasorri F, Pallotta S, Cianfarani F, Odorisio T, Traidl-Hoffmann C, Behrendt H, Durham SR, Schmidt-Weber CB, Cavani A., J. Clin. Invest. 119, 3573-3585, 2009.

Favre D, Mold J, Hunt PW, Kanwar B, Loke P, Seu L, Barbour JD, Lowe MM, Jayawardene A, Aweeka F, Huang Y, Douek DC, Brenchley JM, Martin JN, Hecht FM, Deeks SG, McCune JM., J. Clin. Invest. 119, 3573-3585, 2010.

Feng D, Kong X, Weng H, Park O, Wang H, Dooley S, Gershwin ME, Gao B., Gastroenterology 143,188-198,2012. https:// doi.org/10.1053/j.gastro.2012.03.044

Fields PE, Kim ST, Flavell RA., J. Immunol. 169, 647-650, 2002. https://doi.org/10.4049/jimmunol.169.2.647

Fulton RB, Meyerholz DK, Varga SM., J. Immunol.185, 2382-2392, 2010. https://doi.org/10.4049/jimmunol.1000423

Gao Y, Zhang M, Li J, Yang M, Liu Y, Guo X, Li H, Liu Z, Zhao J., PLoS One 10, e0137881, 2015. https://doi.org/10.1371/ journal.pone.0137881

Ge J, Wang K, Meng QH, Qi ZX, Meng FL, Fan YC., J. Clin. Immunol. 1, 60-67, 2010. https://doi.org/10.1007/s10875009-9328-2

Gensous N, Charrier M, Duluc D, Contin-Bordes C, Truchetet ME, Lazaro E, Duffau P, Blanco P, Richez C., Front. Immunol. 9,1637,2018.https://doi.org/10.3389/fimmu.2018.01637

González PA, Bueno SM, Carreño LJ, Riedel CA, Kalergis AM., Rev. Med. Virol. 22, 230-244, 2012. https://doi. org $/ 10.1002 / \mathrm{rmv} .1704$

Gorenec L, Zidovec Lepej S, Grgic I, Planinic A, Iscic Bes J, Vince A, Begovac J., Microb. Pathog. 97, 125-130, 2016. https:// doi.org/10.1016/i.micpath.2016.06.008

Goswami R, Kaplan MH., J. Immunol. 189, 3026-3033, 2012a. https://doi.org/10.4049/jimmunol.1201496
Goswami R, Jabeen R, Yagi R, Pham D, Zhu J, Goenka S, Kaplan MH., J. Immunol. 188, 968-975, 2012b. https://doi. org/10.4049/jimmunol.1102840

Graham MB, Braciale VL and Braciale TJ., J. Exp. Med. 180, 1273-1282,1994. https://doi.org/10.1084/jem.180.4.1273

Grogan JL, Mohrs M, Harmon B, Lacy DA, Sedat JW, Locksley RM., Immunity 14, 205-215, 2001. https://doi. org/10.1016/S1074-7613(01)00103-0

Guo XJ, Dash P, Crawford JC, Allen EK, Zamora AE, Boyd DF, Duan S, Bajracharya R, Awad WA, Apiwattanakul N, Vogel P, Kanneganti TD, Thomas PG., Immunity 49, 531-544.e6, 2018. https://doi.org/10.1016/j.immuni.2018.07.011

Han SC, Kang GJ, Ko YJ, Kang HK, Moon SW, Ann YS, Yoo ES., BMC Immunol. 13, 1-12, 2012. https://doi.org/10.1186/14712172-13-44

Haynes NM, Allen CD, Lesley R, Ansel KM, Killeen N, Cyster JG., J. Immunol. 179, 5099-5108, 2007. https://doi. org/10.4049/iimmunol.179.8.5099

Hori S, Nomura T, Sakaguchi S., Science. 299, 1057-1061, 2003. https://doi.org/10.1126/science.1079490

Hwang ES, Szabo SJ, Schwartzberg PL, Glimcher LH., Science. 307, 430-433, 2005. https://doi.org/10.1126/science. 1103336

Ise W, Kohyama M, Schraml BU, Zhang T, Schwer B, Basu U, Alt FW, Tang J, Oltz EM, Murphy TL, Murphy KM., Nat. Immunol. 12, 536-543, 2011. https://doi.org/10.1038/ $\underline{\text { ni.2037 }}$

Itohara S, Farr AG, Lafaille JJ, Bonneville M, Takagaki Y, Haas W, Tonegawa S., Nature. 343, 754-757, 1990. https://doi. org/10.1038/343754a0

Ivanov II1, McKenzie BS, Zhou L, Tadokoro CE, Lepelley A, Lafaille JJ, Cua DJ, Littman DR., Cell 126, 1121-1133, 2006. https://doi.org/10.1016/i.cell.2006.07.035

Jabeen R, Goswami R, Awe O, Kulkarni A, Nguyen ET, Attenasio A, Walsh D, Olson MR, Kim MH, Tepper RS, Sun J, Kim CH, Taparowsky EJ, Zhou B, Kaplan MH., J. Clin. Invest. 123, 4641-4653, 2013. https://doi.org/10.1172/JCI69489

Jabeen R, Kaplan MH., Curr. Opin. Immunol. 24, 303-307, 2012. https://doi.org/10.1016/i.coi.2012.02.001

James KS, Trumble I, Clohosey ML, Moeser M, Roan NR, Adimora AA, Joseph SB, Archin NM, Hudgens M, SorianoSarabia N., AIDS 34, 363-371, 2020.

Jandl C, Loetsch C, King C., Methods Mol. Biol.1623, 95-103, 2017. https://doi.org/10.1007/978-1-4939-7095-7 8

Kaplan MH, Wurster AL, Grusby MJ., J. Exp. Med. 188, 1191-1196, 1998. https://doi.org/10.1084/jem.188.6.1191

Kaplan MH., Immunol. Rev. 252, 104-115, 2013. https://doi. org/10.1111/imr.12028

Khan WI, Richard M, Akiho H, Blennerhasset PA, Humphreys NE, Grencis RK, Van Snick J, Collins SM., Infect. Immun. 71, 2430-2438, 2003. https://doi.org/10.1128/ IAI.71.5.2430-2438.2003

Kim CJ, Nazli A, Rojas OL, Chege D, Alidina Z, Huibner S, Mujib S, Benko E, Kovacs C, Shin LY, Grin A, Kandel G, Loutfy M, Ostrowski M, Gommerman JL, Kaushic C, Kaul R., Mucosal Immunol., 5, 670-680, 2012. https://doi. org/10.1038/mi.2012.72 
King C, Tangye SG, Mackay CR., Annu. Rev. Immunol. 26, 741-766, 2008. https://doi.org/10.1146/annurev.immu$\underline{\text { nol.26.021607.090344 }}$

Kinter A, McNally J, Riggin L, Jackson R, Roby G, Fauci AS., Proc. Natl. Acad. Sci USA 104, 3390-3395, 2007. https://doi. org/10.1073/pnas.0611423104

Korn T, Bettelli E, Oukka M, Kuchroo VK., Annu. Rev. Immunol. 27, 485-517, 2009. https://doi.org/10.1146/annurev.immunol.021908.132710

Kurata H, Lee HJ, O'Garra A, Arai N., Immunity 11, 677-688, 1999. https://doi.org/10.1016/S1074-7613(00)80142-9

Lachová V, Škorvanová L, Svetlíková D, Turianová L, Kostrábová A, Betáková T., Acta Virol. 61,183-190, 2017. https://doi. org/10.4149/av 20170207

Lambrecht BN, Hammad H., Annu. Rev. Immunol. 30, 243270, 2012. https://doi.org/10.1146/annurev-immunol-020711-075021

Laurence A, Tato CM, Davidson TS, Kanno Y, Chen Z, Yao Z, Blank RB, Meylan F, Siegel R, Hennighausen L, Shevach EM, O'shea JJ., Immunity 26, 371-381, 2007. https://doi. org/10.1016/j.immuni.2007.02.009

Lee GR, Fields PE, Griffin TJ, Flavell RA., Immunity 19, 145-153, 2003. https://doi.org/10.1016/S1074-7613(03)00179-1

Lee HJ, Takemoto N, Kurata H, Kamogawa Y, Miyatake S, O'Garra A, Arai N., J. Exp. Med. 192, 105-115, 2000. https://doi. org/10.1084/jem.192.1.105

Li P, Spolski R, Liao W, Wang L, Murphy TL, Murphy KM, Leonard WJ., Nature 490,543-546,2012.https://doi.org/10.1038/ $\underline{\text { nature } 11530}$

Liston A, Gray DH., Nat. Rev. Immunol. 14, 154-65, 2014. https:// doi.org/10.1038/nri3605

Lu C, Zanker D, Lock P, Jiang X, Deng J, Duan M, Liu C, Faou P, Hickey MJ, Chen W., Immunol. Cell Biol. 97, 774-786, 2019. https://doi.org/10.1111/imcb.12271

Maeda Y, Nishikawa H, Sugiyama D, Ha D, Hamaguchi M, Saito T, Nishioka M, Wing JB, Adeegbe D, Katayama I, Sakaguchi S., Science 346,1536-1540, 2014. https://doi. org/10.1126/science.aaa1292

Malek TR, Castro I, Immunity 33, 153-165, 2010. https://doi. org/10.1016/j.immuni.2010.08.004

Meng F, Wang K, Aoyama T, Grivennikov SI, Paik Y, Scholten D, Cong M, Iwaisako K, Liu X, Zhang M, Österreicher CH, Stickel F, Ley K, Brenner DA, Kisseleva T., Gastroenterology 143, 765-776, 2012. https://doi.org/10.1053/j. gastro.2012.05.049

Miyauchi K., Viral. Immunol. 30, 421-430, 2017. https://doi. org/10.1089/vim.2017.0018

Mo R, Wang P, Lai R, Li F, Liu Y, Jiang S, Zhao G, Guo S, Zhou H, Lin L, Lu J, Cai W, Wang H, Yu H, Bao S, Xiang X, Xie Q., J. Gastroenterol. Hepatol.32,677-686, 2017. https://doi. org/10.1111/igh.13537

Moser EK, Hufford MM, Braciale TJ., PLoS Pathog. 10, e1004315, 2014. https://doi.org/10.1371/journal.ppat.1004315

Mosmann TR, Cherwinski H, Bond MW, Giedlin MA, Coffman RL., J. Immunol. 136, 2348-2357, 1986.

Mukherjee S, Lindell DM, Berlin AA, Morris SB, Shanley TP, Hershenson MB, Lukacs NW., Am. J. Pathol.1,248-258, 2011. https://doi.org/10.1016/j.ajpath.2011.03.003
Nedellec S, Sabourin C, Bonneville M, Scotet E., J. Immunol.185, 55-63,2010. https://doi.org/10.4049/jimmunol.1000373

Nograles KE, Zaba LC, Shemer A, Fuentes-Duculan J, Cardinale I, Kikuchi T, Ramon M, Bergman R, Krueger JG, GuttmanYassky E., J. Allergy Clin. Immunol.123, 1244-1252 e1242, 2009. https://doi.org/10.1016/j.jaci.2009.03.041

Oh S, Eichelberger MC., J. Virol. 74, 7738-7744, 2000. https://doi. org/10.1128/JVI.74.17.7738-7744.2000

Orlova-Fink N, Chowdhury FZ, Sun X, Harrington S, Rosenberg ES, Yu XG, Lichterfeld M., AIDS 31, 2211-2215, 2017. https://doi.org/10.1097/QAD.0000000000001630

Otsuka A, Hanakawa S, Miyachi Y, Kabashima K, J., Allergy Clin. Immunol.132,1448-1451,2013. https://doi.org/10.1016/j. jaci.2013.05.037

Ouyang W, Löhning M, Gao Z, Assenmacher M, Ranganath S, Radbruch A, Murphy KM., Immunity 12, 27-37, 2000. https://doi.org/10.1016/S1074-7613(00)80156-9

Park SY, Gupta D, Kim CH, Dziarski R., PLoS One. 6, e24961, 2011. https://doi.org/10.1371/journal.pone.0024961

Paul WE, Zhu J., Nat. Rev. Immunol. 10, 225-235, 2010. https:// doi.org/10.1038/nri2735

Plank MW, Kaiko GE, Maltby S, Weaver J, Tay HL, Shen W, Wilson MS, Durum SK, Foster PS., J. Immunol. 198, 2182-2190, 2017. https://doi.org/10.4049/iimmunol.1601480

Pulendran B, Artis D., Science. 337, 431-435, 2012. https://doi. org/10.1126/science.1221064

Ramirez JM, Brembilla NC, Sorg O, Chicheportiche R, Matthes T, Dayer JM, Saurat JH, Roosnek E, Chizzolini C., Eur. J. Immunol.40,2450-2459,2010. https://doi.org/10.1002/ eji.201040461

Rei M, Gonçalves-Sousa N, Lança T, Thompson RG, Mensurado S, Balkwill FR, Kulbe H, Pennington DJ, Silva-Santos B., Proc. Natl.Acad.Sci.USA 111, E3562-3570, 2014. https:// doi.org/10.1073/pnas.1403424111

Reiner SL, Locksley RM., Annu. Rev. Immunol. 13, 151-177, 1995. https://doi.org/10.1146/annurev.iy.13.040195.001055

Reuter MA, Pombo C, Betts MR., Cyt. Growth Factor Rev. 23,181191, 2012. https://doi.org/10.1016/j.cytogfr.2012.05.005

Ribot JC, deBarros A, Pang DJ, Neves JF, Peperzak V, Roberts SJ, Girardi M, Borst J, Hayday AC, Pennington DJ, SilvaSantos B., Nat. Immunol.10, 427-436, 2009. https://doi. org/10.1038/ni.1717

Rochman Y, Spolski R, Leonard WJ., Nat. Rev. Immunol. 9, 480-490, 2009. https://doi.org/10.1038/nri2580

Ruckwardt TJ, Bonaparte KL, Nason MC, Graham BS., J. Virol. 83, 3019-3028, 2009. https://doi.org/10.1128/JVI.00036-09

Sakaguchi S, Miyara M, Costantino CM, Hafler DA., Nat. Rev. Immunol. 10, 490-500, 2010. https://doi.org/10.1038/ $\underline{\text { nri2785 }}$

Sakaguchi S, Yamaguchi T, Nomura T, Ono M., Cell 133, 775-787, 2008. https://doi.org/10.1016/i.cell.2008.05.009

Sallusto F, Lenig D, Mackay CR, Lanzavecchia A., J. Exp. Med. 187,875-883,1998. https://doi.org/10.1084/jem.187.6.875

Saluzzo S, Gorki AD, Rana BMJ, Martins R, Scanlon S, Starkl P, Lakovits K, Hladik A, Korosec A, Sharif O, Warszawska JM, Jolin H, Mesteri I, McKenzie ANJ, Knapp S., Cell Rep. 18, 1893-1905, 2017. https://doi.org/10.1016/j. celrep.2017.01.071 
Santegoets SJ, Dijkgraaf EM, Battaglia A, Beckhove P, Britten CM, Gallimore A, Godkin A, Gouttefangeas C, de Gruijl TD, Koenen HJ, Scheffold A, Shevach EM, Staats J, Taskén K, Whiteside TL, Kroep JR, Welters MJ, van der Burg SH., Cancer Immunol. Immunother. 64, 1271-1286, 2015. https://doi.org/10.1007/s00262-015-1729-x

Sarda C, Palma P, Rello J., Curr. Opin. Crit. Care. 25, 449-457, 2019.https://doi.org/10.1097/MCC.0000000000000638

Shi H, Liu C, Tan H, Li Y, Nguyen TM, Dhungana Y, Guy C, Vogel P, Neale G, Rankin S, Feng Y, Peng J, Tao W, Chi H., Immunity. 49, 899-914, 2018. https://doi.org/10.1016/j. immuni.2018.10.010

Shirazi Y, Pitha PM., J. Virol. 66, 1321-1328, 1992. https://doi. org/10.1128/JVI.66.3.1321-1328.1992

Schmitt E, Germann T, Goedert S, Hoehn P, Huels C, Koelsch S, Kühn R, Müller W, Palm N, Rüde E., J. Immunol. 153, 3989-3996, 1994.

Schraml BU, Hildner K, Ise W, Lee WL, Smith WA, Solomon B, Sahota G, Sim J, Mukasa R, Cemerski S, Hatton RD, Stormo GD, Weaver CT, Russell JH, Murphy TL, Murphy KM., Nature 460, 405-409, 2009. https://doi. org/10.1038/nature08114

Sonnenberg GF, Fouser LA,Artis D., Nat.Immunol.12,383-390,2011 https://doi.org/10.1038/ni.2025

Staudt V, Bothur E, Klein M, Lingnau K, Reuter S, Grebe N, Gerlitzki B, Hoffmann M, Ulges A, Taube C, Dehzad N, Becker M, Stassen M, Steinborn A, Lohoff M, Schild H, Schmitt E, Bopp T., Immunity 33, 192-202,2010. https:// doi.org/10.1016/j.immuni.2010.07.014

Sun X, Shibata K, Yamada H, Guo Y, Muta H, Podack ER, Yoshikai Y., Mucosal Immunol. 6, 1191-1201, 2013. https://doi. org/10.1038/mi.2013.18

Szabo SJ, Kim ST, Costa GL, Zhang X, Fathman CG, Glimcher LH., Cell 100, 655-669, 2000. Škorvanová L, Švančarová P, Svetlíková D, Betáková T., Acta Virol. 59, 413-417, 2015. https://doi.org/10.1016/S0092-8674(00)80702-3

Škorvanová L, Švančarová P, Svetlíková D, Betáková T., Acta Virol. 59, 413-417, 2015.

Švančarová P, Svetlikova D, Betakova T., Virus Res. 195, 100-111, 2015a. https://doi.org/10.1016/i.virusres.2014.08.004

Švančarová P, Svetlíková D, Betáková T., Acta Virol. 59, 148-155, 2015b. https://doi.org/10.4149/av_2015_02_148

Takemoto N, Arai K, Miyatake S., J. Immunol. 169, 4103-4107, 2002. https://doi.org/10.4049/jimmunol.169.8.4103

Temann UA, Geba GP, Rankin JA, Flavell RA., J. Exp. Med. 188, 1307-1320,1998. https://doi.org/10.1084/jem.188.7.1307

Teng DK, Liu Y, Lv YF, Wang L, Zhang W, Wang JP, Li Y., Int. Immunopharmacol. 70, 252-259, 2019. https://doi. org/10.1016/j.intimp.2019.02.048

Thompson CL, Plummer SJ, Tucker TC, Casey G, Li L., Cancer Causes Control 8, 1165-1170, 2010. https://doi. org/10.1007/s10552-010-9542-5

Turianová L, Lachová V, Svetlíkova D, Kostrábová A, Betáková T., Exp. Ther. Med. 18, 4397-4405, 2019.

Turianová L, Lachová V, Svetlíkova D, Kostrábová A, Tokárová K, Betáková T., Acta Virol. 64, 78-87, 2020. https://doi. org/10.4149/av_2020_110
Unutmaz D., Eur. J. Immunol. 39, 1452-145, 2009. https://doi. org/10.1002/eji.200939540

Usui T, Nishikomori R, Kitani A, Strober W., Immunity 18,415-428, 2003. https://doi.org/10.1016/S1074-7613(03)00057-8

Vantourout P, Hayday A., Nat. Rev. Immunol. 13, 88-100, 2013. https://doi.org/10.1038/nri3384

Vantourout P, Willcox C, Turner A, Swanson CM, Haque Y, Sobolev O, Grigoriadis A, Tutt A, Hayday A., Sci. Trans. Med. 6, 1-32, 2014.

Veazey RS., Curr. Immunol. Rev. 15, 76-91, 2019. https://doi.org/ $10.2174 / 1573395514666180605083448$

Veldhohen M, Uyttenhove C, van Snick J, Helmby H, Westendorf A, Buer J, Martin B, Wilhelm C, Stockinger B., Nat. Immunol. 9, 1341-1346, 2008. https://doi.org/10.1038/ ni.1659

Walsh PT, Buckler JL, Zhang J, Gelman AE, Dalton NM, Taylor DK, Bensinger SJ, Hancock WW, Turka LA., J. Clin. Invest. 116, 2521-2531, 2006.

Wang B, Zhao XP, Fan YC, Zhang JJ, Zhao J, Wang K., Antiviral Res. 97, 285-292, 2013. Wang L, Kang N, Zhou J, Guo Y, Zhang X, Cui L, Ba D, He W., Scand. J. Immunol. 76, 62-69, 2012. https://doi.org/10.1016/j.antiviral.2012.12.018

Wang B, Zhao XP, Fan YC, Zhang JJ, Zhao J, Wang K., Antiviral Res. 97, 285-292, 2013.

Wang Y, Wang L, Gao W, Chen Y, Su Y., Exp. Ther. Med. 16, 1328-1332, 2018.

Yamashita M, Ukai-Tadenuma M, Kimura M, Omori M, Inami M, Taniguchi M, Nakayama T., J. Biol. Chem. 277, 4239942408, 2002. https://doi.org/10.1074/ibc.M205876200

Yang WY, Shao Y, Lopez-Pasrana J, Mai J, Wang J, Yang XF, Burns Trauma. 3, 1-11, 2015. https://doi.org/10.1186/ s41038-015-0001-0

Yang XO, Pappu B, Nurieva R, Akimzhanov A, Kang HS, Chung Y, Ma L, Shah B, Panopoulos AD, Schluns K, Watowich SS, Tian Q, Jetten AM, Dong C., Immunity 28, 29-39, 2007. https://doi.org/10.1016/j.immuni.2007.11.016

Yeste A, Mascanfroni ID, Nadeau M, Burns EJ, Tukpah AM, Santiago A, Wu C, Patel B, Kumar D, Quintana FJ., Nat. Commun.5,1-13,2014. https://doi.org/10.1038/ncomms4753

Yoon SW, Wong SS, Zhu H, Chen R, Li L, Zhang Y, Guan Y, Webby RJ., J. Infect. Dis. 217,438-442, 2018. https://doi. org/10.1093/infdis/jix328

Zhang JY, Zhang Z, Lin F, Zou ZS, Xu RN, Jin L, Fu JL, Shi F, Shi M, Wang HF, Wang FS., Hepatology 1, 81-91, 2010. https:// doi.org/10.1002/hep.23273

Zhao J, Zhang Z, Luan Y, Zou Z, Sun Y, Li Y, Jin L, Zhou C, Fu J, Gao B, Fu Y, Wang FS., Hepatology 59, 1331-1342, 2014. https://doi.org/10.1002/hep.26916

Zhou L, Chong MM, Littman DR., Immunity 30, 646-55, 2009. https://doi.org/10.1016/j.immuni.2009.05.001

Zhou L, Lopes JE, Chong MM, Ivanov II, Min R, Victora GD, Shen Y, Du J, Rubtsov YP, Rudensky AY, Ziegler SF, Littman DR., Nature 453,236-240,2008. https://doi.org/10.1038/ nature06878 